\title{
脳梗塞急性期にお引る血行再開に伴う出血性梗塞
} 一実験的研究-

\author{
甲州 啓二・吉本 高志・鈴木 二郎
}

\section{Experimental Study on Hemorrhagic Infarction following Recirculation in Thalamic Ischemic Lesion}

\author{
Keju Koshu, Takashi Yoshimoto and Jiro Suzuki \\ Division of Neurosurgery, Institute of Brain Diseases, Tohoku University, Sendai 982
}

\begin{abstract}
Summary
Brain infarction confined to the anterior half of the thalamus can be produced in dogs by simultaneously occluding 4 main arteries ipsilaterally at the base of the brain (the internal carotid, the anterior cerebral, the middle cerebral, and the posterior communicating arteries). Using this "thalamic infarction model in the dog", hemorrhagic infarction following recirculation was investigated.

In animals undergoing 6-12 hour occlusion, a high incidence of hemorrhagic infarction was found following rccirculation. Notably, in brains autopsied 1 hour after recirculation, hemorrhagic infarction was seen in all $(100 \%)$ of the dogs.
\end{abstract}

Key words : hemorrhagic infarction, thalamus, dogs

\section{Iはじめに}

近年, 脳血管閉塞性疾患に対する血行再建術の開発が 進み，それ儿伴って，脳梗塞の病態生理む次第に解明し つつある。しかし，血行再建術の適㐫については未だ確 たる定説飪い，特に，その手術時期法，血行再開に よる臨床症状の悪化等もあって, 暗中模索の状態であ $る^{127133 .}$ ，它の悪化の原因としては，血行再開後の脑浮 腫および出血性㤦塞の発現等が举げられているが，その よってくる病態生理の本質の解明は，未だまったく不十 分である。

本論文は，出血性梗塞の病態の解明を目的として，す

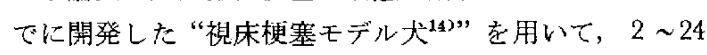
㭙間の血流遮断後の脳梗塞巣に血行を再開させる実験を 行い，出血性梗塞栄安高頻度に作製することに成功した
ので，まずその事実を報告して考察を加えた。

\section{I 実 験 方 法}

\section{1. 実験動物および方法}

㬰験動物として，22頭の，体重約 $10 \mathrm{~kg}$ の雑種成犬を用 いまず，“視床梗塞モデル犬゙””を作製した，その詳細 は省略するが, Nembutal (35 mg/ $\mathrm{kg}$ )の静脈麻酔下に気 管内㨉管し，自発呼吸のまま右側頭開頭を行い，顕微鏡 下に, 内顓動脈, 前大脳動脈, 中大脳動脈, 拉よび後交通 動脈の 4 動脈を, Scoville 型クリップにて同時に遮断 し，全例に視床脳波交記録し，血管遮断後，脳波上虚血 性変化を示したもののみを用いだ2。血管遮断後代用硬 膜で譄表を保護し，筇層，頭皮の縫合を行った，遮断時 間は，2，3，6，9，12扔上び24時間とし，各々の時間の 遮断後, 再度 Nembutal 静脈麻酔下に遮断クリップを解

東北大学譄研脳神経外科

[連絡先：干982 仙台市長町5-13-1, 東北大学脳研媨神経外科, 甲州啓二]

1980年3月 3 日 受稿 


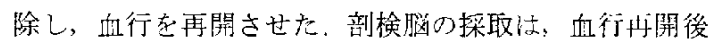
5 分または 1 時間の㭙点で，腹部大動脈上り力テーテ 儿在挿入し，先端孝卜行大動脈心位置に招き，上行大 動脈在結㯏し，同時にあら加じ露出しておいた到静

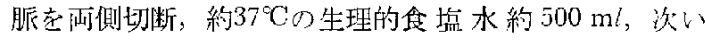
で 4\%paraformaldehyde - $5 \%$ glutaraldehyde 液 $500 \sim$ $800 \mathrm{~m} l$ t, 灌流圧 $120 \mathrm{~mm} \mathrm{Hg}$ て注入, 脳交灌流固定した (Table 1). 固定後宅温にて 2 時閒故置した後, 胹摘 出し，再げ周定液に浸透し，一部计電顕標本，残りを光 䫓標本用に供した。 な扔，全例白発呼吸下に，血圧は大 腿動脈の cannulation t用い，持続测定し，術中の血止 変動の無いことを確認した。

\section{2. 出血性梗塞の判定}

剖検脑は，視交叉部上り $5 \mathrm{~mm}$ 後方の能額断面で，右

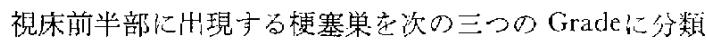
して検討した（Table 2)，すなわち Grade０任，肉眼的 にも炎頙上でも出血の諗站られないもの, Grade I 泳,

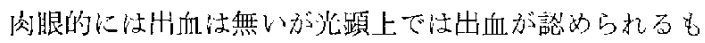
の，そしてGrade II 泣，肉眼的にも明らかな出血在認 めたもので志る(Fig.1)。

\section{II 実 験 結 果}

2 時間遮断例では, 血行再開 5 分後, および 1 時閒後

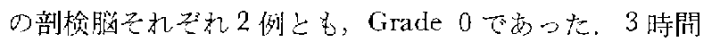

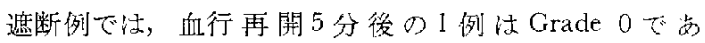
り，1 時間後の4例では， 1 例が Grade $0 ， 3$ 例が Grade Iであった。 6 時間遮断例で法，血行再開 5 分後 の 3 例中 1 例が Grade I, 他の 2 例は Grade II で り，血行再開 1 時間後の 1 例は Grade II でむった。 9 時問就よび12時䦗遮断例では，血行两開時間に関倸な く、4例とも Grade II であった. 24時間遮断例では。 血行再開 5 分後 $\sigma 2$ 例法, 抒の抒 $D$ Grade I, Grade

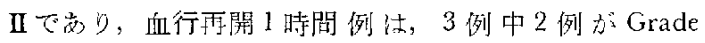
I，1例㣻 Grade II で每った (Fig. 2)。

\section{V 考按}

従来より脑楂塞の実験モデルとしては，種々の動物を 用いて数多くの実駼名行わ扎ている，このうち出向性埂

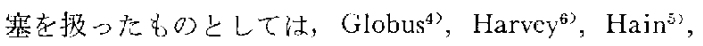
Faris ${ }^{32}$ らの報少が見ら机るか，それらは microsurgical technique を用いていない時期のものであり，末た， Globus，Farisは，吕压の上での病態解明ということで間 題が多い，

最近 Crowell ら”は，サルの中大媨動脈遮断し，4 時間以内に血行再開した群と, 永久遌断群で, 梗塞单
Table 1 Numbers of dog used in the experiment.

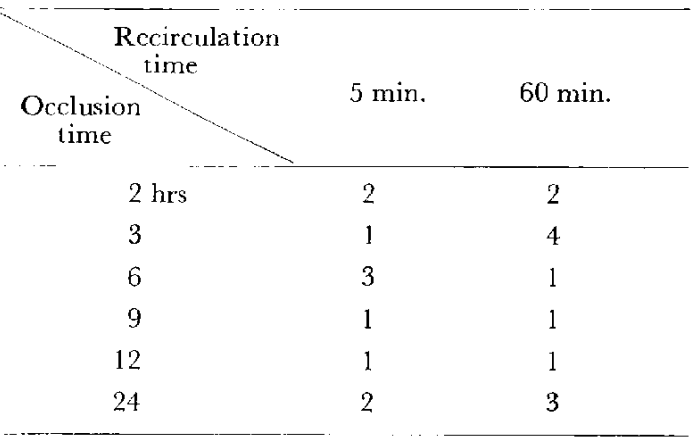

Table 2 Grading of hemorrhagic infarction

Grade 0: palc infarction without microscopical bleeding

Grade I: pale infarction with microscopical

Grade II : hemorrhagic infarction

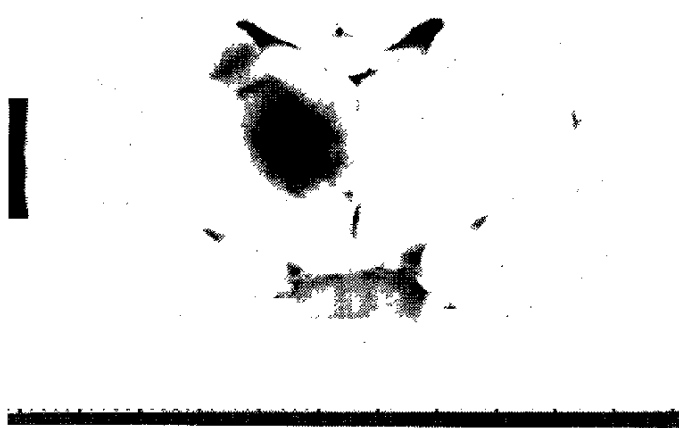

Fig. I Thalamic infarction of Gradc II produced by temporary clipping for 6 hours followed by 1 hour recirculation.

を作るものの出血壮諗的られず，6〜24時間の遮断後に 血行妌開在行った群では，斗数汇出血性梗塞が認方られ

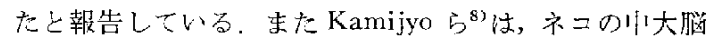
動脈遮断 1 時間捘の血行再開で注出血性梗塞は东ったく 認的られず，6時䦎後に血行再開を行った群ては40\%， 24 㭙問传では60\%に出血性梗塞が認的られたとしてい

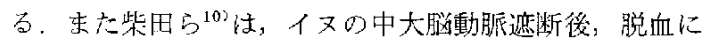
よって1時間血左孛 $50 \mathrm{~mm} \mathrm{Hg}$ に低下させ，その後その

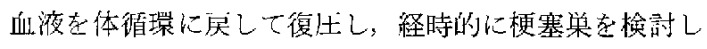
ているが，その24時問後に注全例に出血性梗塞加諮めら 


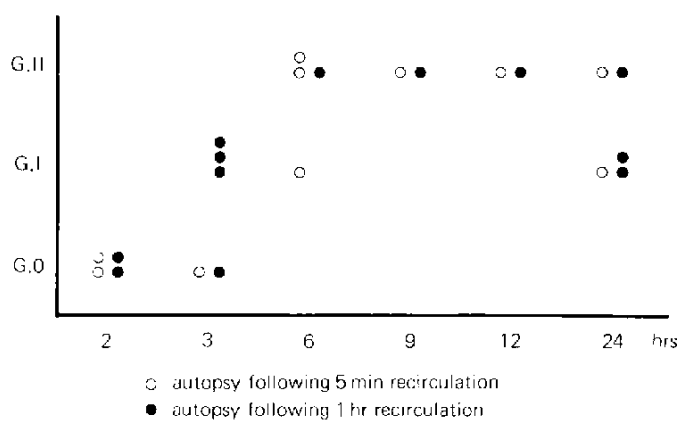

Fig. 2 Correlation betwecn acclusion time and hemorrhagic infarction. G: Grade

れたとしている。

一般に動物の腷は，collateral circulation が発達して おるり，中大脳動脈のみの遮断では，一定部位に简頻度に 梗塞巣を作製することは因難であり，したがって，出血 性梗塞を高嚬度に発現させるモデルとしては不卜分であ る上思加机る。さら低血圧操作を加えることは, 出血 性梗塞の発現頻度は高いが，脱血といら非生理的な蜗作 を要する点が難点である。

今可, “視休梗塞モデル犬14”の特長, 寸なおち梗塞発 生部位が一定しており，絪波を併用することによりはぼ $100 \%$ に梗塞巣が得られ死ことき, さらに，血行再開が比 較的容员に行いらることなどの利点を用いて，出血性梗 塞の作製を試みた，その結果，2 時閒抢よび 3 時間の血 流遮断後に血行再開を行った群では，全例梗塞采に出血 は譛められず， $6 \sim 12$ 時間遮断暏に血行再開を行った 8 例中 7 例 $(87.5 \%)$ に流明占加な山血性梗塞が諗めら 九，特に血行再開 1 時間の剖検脳では，全例に出血性梗 塞怔認めら孔た。一方，24恃閒遮断後に血行再開を行っ た群では，5例中 2 例に山血性梗寒巣が諗められていた にすぎず， $6 \sim 12$ 時間遮断後の血行再開群と比べるとそ の発現頻优は低かった。この事害は䀧味のあることであ り,さらに長時間遮断後の血行再開の昜合, 梗塞紧がど の上うな態度を示寸ものか今後の検炋に期待したい.

出血性梗塞のメカ二ズムは今な打不明な点が多いが， 今回用いた“視床梗塞モデル犬゙”では，6〜12時間の血流 遮断後に 1 時間 0 血行再開老行えば， 100\%出血性梗塞 大を得ることが判った。この事生から本法を用い机恬， 出血性梗塞のメカニズムその他の礼明が可能であると考 える，すでに我々は“視床梗塞モデル犬”を用いて，15 分 24 時間の永久遮断実験在行い，脳梗塞岀の神経細 胞 ${ }^{11}$ 坊よび血管系の経時的賕化 ${ }^{12}$ を追求したがここれら の永久遮断群では，出和性梗塞は一例も認められなかっ た. 今後さらに, 出血性梗塞紧の組織学的変化, 局所媨
湎環，CT スキャン等の経時的変化についても追求し， 稿主改好て報告したい。

\section{V 結 語}

1. 我々がすでに発表している，イヌ脳底部一側 4 動 脈 (内頸動脈, 前大脑動脈, 中大脳動脈, 後交通動脈) 文同時に遮断して，視床前半部に脳梗塞坚を限局的に出 現させることができる“視休梗塞モデル犬”艺用いて， 血行再開後の出血性梗塞の発現について検討した。

2. 遮断時間が $6 \sim 12$ 時間の群では, 血行再開後高頻 度に出血性梗塞が発現した，特に血行再開 1 時間後の剖 検腷では，100\%に出血性梗塞が得られた。

本諭文の要旨は第38回日本腷社䅅外科学会総会 年10月，於東京)に抬いて発表した。

\section{文献}

1) Caplan, L. R., Skillman, J., Ojemann, R. \& Fielos, W. S.: Intracerebral hemorrhage following carotid endarterectomy: A hypertensive complication? Stroke 9: 457-460, 1978

2) Crowell, R. M., Olsson, Y., Klatzo, I. \& Ommaya, A.: Temporary occlusion of the middle cerebral artery in the monkey: Clinical and pathological observations. Stroke 1: $439-448$, 1970

3) Faris, A., Hardin, C. A. \& Poser, C. M.: Pathogenesis of hemorrhagic infarction of the brain. 1. Experimental investigation of role of hypertension and of collateral circulation. Arch Neural 9: 468-472, 1963

4) Globus, J. \& Epstein, A.: Massive cerebral hemorrhage: Spontaneous and experimentally induced. $J$ Neuropathol Exp Neurol 12: 107-131, 1953

5) Hain, R. F., Westhaysen, P. V. \& Swank, R. L.: Hcmorrhagic cerebral infarction by arterial occlusion. I Neuropathol Exp Neurol 11: 34-43, 1952

6) Harvey, J. \& Rasmussen, T.: Occlusion of the middlc cercbral artery. An experimental study. Arch Neurol Psychiat 66: 20-29, 1951

7) 入野忠芳：脳血管閉塞の再開通現象，脳神経 $30: 135-151,1978$

8) Kamijyo, T., Garcia, J. H. \& Cooper, J.: Temporary regional cerebral ischemia in the cat. A model of hemorrhagic and subcortical infarction. $J$ Neuropathol Exp Neurol 36: 338-350, 1979

9）坂本哲也，田中悟，吉本高志，渡辺考男，鈴 木二郎：実験的脳梗塞（第 2 報）一視床梗塞 モ 
デル犬の局所脑波の変化とその応用. 眇外 6： 453-457, 1978

10）柴田尚武，安永暁生，森 和夫：脳梗塞に関す る実験的研究（第 I 報）一出血性梗塞の発生 機 序について一. Neurol Med Chir 18:377-383, 1978

11）渡辺孝男, 吉本高志, 田中 悟, 嘉山孝正, 坂 本哲也, 鈴木二郎：脳梗塞の形成過程一実験的, 電顕的研究一第一報 神释細胞の变化. Neurol Med Chir 19: 279-285, 1979

12）渡辺孝男，吉本高志，甲州啓二，坂本哲也，
関 博文,鈴木二郎：脳梗塞の形成過程一実験的, 電顕的研究一第二報 小血管の変化. Neurol Med Chir 19: 811-816, 1979

13) Wyle, E. J., Hein, M. F. \& Adams, J. E.: Intracranial hemorrhage following surgical revascularization for treatment of acute stroke. $J$ Neurosurg 21:212-215, 1964

14）吉本高志, 坂本哲也, 鈴木二郎：実験的 脳 梗 塞 (第 $\mathrm{l}$ 報)一視床梗塞モデル犬の作製一. 脳 外 $6: 355-359,1978$ 